\title{
Gender Policy and European Integration
}

\author{
Ma. Rediana Bajrami \\ Department of Economy Cooperation \\ Specialist, Ministry of Economy, Trade and Energy, Tirana-Albania \\ Mob: 00355692154732, Mail: redi_pnl@yahoo.com \\ Eneida Capo \\ Department of Social Service Policies, \\ Specialist, Ministry of Labor, Social Affairs and Equal Opportunities , Tirana-Albania \\ Mob: 00355674093485, Mail: eneida_cp@yahoo.com
}

Doi:10.5901/mjss.2013.v4n9p141

Abstract

This article will focus on gender mainstreaming as a strategy for achieving gender equality and the fight against domestic violence, the progressive harmonization of national legislation with the European Community legislation (acquiscommunautaire), the international legal framework as well as national policies and mechanisms for achieving gender equality in Albania.In most modern democracies the concept of equality before the law excludes any possibility of discrimination on the basis (ethnic origin, social, sex, religion, etc.) and it is a cornerstone concept of a democratic development in an emancipated society. Albania's ability to meet the commitments set out in the Stabilization and Association Agreement is the most important criterion to assess its readiness for further advancement towards full membership in the European Community. Fulfillment of commitments under this Agreement, marks the beginning of a comprehensive reform of state governance and society as a whole, in order to adapt to the political, legal, economic and institutional standards of the European Union. Description of the current situation, problems and achievements in the field of gender equality and domestic violence, will be analyzed in this article.

Keywords: legal framework, gender mainstreaming, gender equality, domestic violence.

\section{Introduction}

Albania's integration into the European Union is a major mission and strategic objective of the State. At any time, this objective has found the support of the Albanian Parliament and the general public opinion. In this long way full of challenges, Albania has the support of the European Union EU. Governments of the EU member countries, together with the European Council EC have agreed to expand the European perspective of the countries of South East Europe; a gradual process which carefully managed creates a situation where all parties are winners. Albania is already very close to be part of Europe Union.

\section{Albanian Progress in the EU Integration Process}

Albania's ability to meet the commitments set out in the Stabilization and Association Agreement is the most important criterion to assess its readiness for further advancement towards full membership, prioritizing, planning, monitoring and evaluation of full harmonization of the Albanian legislation with the EU acquis communautaire as an essential condition for Albania membership in the European Union.

By signing the Agreement, Albania undertakes a series of commitments and their implementation within the established deadlines. Deadlines vary depending on the area concerned, while the deadline for meeting the obligations of the Agreement is 10 years from the date of its entry into force. This Agreement entered into force on April 1st, 2009 after the ratification by the European Union and all its Member States. The deadline for the implementation of obligations under the Stabilization and Association Agreement is the March 315t, 2019. In the area of gender equality and women's rights, the National Plan for the Implementation of the Stabilization and Association Agreement pays attention to harmonization of legislation with the EU acquis communautaire in the field of equal opportunities. 


\subsection{European Partnership with Albania}

This document is an instrument of the Stabilization and Association process, through which the aim is to offer further support for the Albanian government for the implementation of European integration. The main requirement set forth in this document is the harmonization of national legislation with the Community. European Partnership with Albania is a reference framework for the financial assistance provided by Community ${ }^{1}$ funds

In particular, on gender equality and women's rights the European Partnership document emphasizes the need for:

- Establishment of a structure within the Ministry of Labor, Social Affairs and Equal Opportunities, currently Department of Equal Opportunities Policy and the Family.

- Further efforts to prevent domestic violence

European Partnership priorities regarding gender equality are:

- Facilitation of the involvement of women in the labor market and their involvement in decision-making processes.

- More efforts to prevent domestic violence

Implementation of the European Partnership with Albania is monitored under the stabilization and association process and its mechanisms. Specifically, the Commission presents its annual report, called Progress Report on Albania. The purpose of the Progress Report is to monitor, assess and report on the achievements of the candidate countries or potential candidates, during the year. In the 2012 Progress Report special attention is given to gender equality, by highlighting the achievements and gaps in this area.

\subsection{As stated in the report:}

"Little progress can be reported in the area of equal opportunities between women and men. There is still a gap between the legal framework and the actual level of equality in relation to employment, pay, access to entrepreneurship and credits. In July 2012, a Council of Ministers decision on gender mainstreaming in the medium-term budget program for all line Ministries was approved. Awareness-raising activities have focused on women's political participation and gender quota, women's entrepreneurship and combating violence against women. However, women continue to be underrepresented in the labor market, in particular in political and economic decision-making. Sufficient financial and human resources are lacking at central and local government levels leading to slow implementation of the 2011-2015 national strategy on gender equality". ${ }^{2}$

\subsection{EU financial support}

The main purpose of the support provided by the EU for Albania, potential EU candidate, is to support the country's progress towards meeting the Copenhagen criteria for its membership and to prepare the country for the EU integration in the future.

\subsection{Instrument for Pre-Accession Assistance IPA}

For candidate countries and potential candidates, programs and financial support of the European Commission are set out in the Instrument for Pre-Accession Assistance. The main objective is to support institutional development and implementation of law, human rights, including minority rights, gender equality and non-discrimination, administrative and economic reforms, economic and social development, reconciliation and reconstruction, as well as regional and crossborder cooperation.

\section{International Legal Framework on Gender Equality Issues and Women's Rights}

Universal Declaration of Human Rights3: The Declaration expresses the rights and fundamental freedoms for men and

\footnotetext{
1 http://www.mie.gov.al/?fq=brenda\&d=6\&gj=gj2\&kid=111

2 http://www.ohchr.org/EN/UDHR/Pages/Introduction.aspx

3 http://www.un.org/womenwatch/daw/cedaw/cedaw.htm adopted by the United Nations Assembly in 1979
} 
women which should be applied without discrimination. Articles 2 and $22-27$, specifically address women's rights. Albania became party in the year 1989.

The Beijing Platform for Action formulated and adopted at the Fourth World United Nations Conference on Women [FWCW] in 1995, a period in which Albania became party and was represented by the central government and civil society. EU has not signed the document as a corporate body, but the ratification of this platform is made individually by its member states. National Strategy for Gender Equality, Reduction of Gender-Based Violence and Domestic Violence, 2011-2015 is designed in full compliance with this document. In implementing this platform Albanian State reports periodically according to the agreed timetable.

Convention on the Elimination of All Forms of Discrimination against Women (CEDAW) 4

This Convention is known as a leading and comprehensive international agreement on women's rights. Albania adhered in the Convention with the Law no. 7767, approved by the Albanian Parliament in 19935. Article 11 stated that countries which have ratified this Convention shall take the necessary measures to ensure equal rights between women and men.

Consisting of 30 articles, it defines what constitutes discrimination against women and sets a program on national action plans to stop gender-based discrimination. The thirty articles of the Convention are based on three basic principles:

States that have ratified the Convention are legally bound to implement in practice the measures provided by this Convention. These countries are also required to prepare national reports, at least every four years, on measures they have taken to meet the obligations of ratifying this Convention. Albania has ratified this convention on May $11^{\text {th }}, 1994$. The Albanian government has submitted a single report ${ }^{6}$, combining the previous report and the second in the $28^{\text {th }}$ session of the Convention, in the year 2003. In 2008 it has been prepared and submitted the third national periodic report on the implementation of this Convention.

\section{European Legal Framework on Gender Policy}

EU legislation in the field of equal opportunities is a result of the Treaty of Amsterdam and includes all EU directives that have come out in support of the Treaty.

Founding Agreement (1957) has some articles that are directly related to gender equality: Article 2: EU should promote equality between men and women.

Article 3 (2): EU in all its activities should... aim to eliminate inequalities and to promote equality between men and women.

Article 13: The Council acting unanimously, on a decision that comes from the EC and after consulting the European Parliament can take action to combat gender discrimination, racial, ethnic, religious or on faith, age or sexual orientation.

Article 141: Each Member State shall ensure the principle of equal pay for men and women workers, for equal work or of equal value.

The approximation of national legislation with EU legislation on gender equality, are as follows:

$41985 \times 0507^{7}$ Resolution of the Council and of the Ministers for Education, meeting within the Council,of 3 June 1985 containing an action programme on equal opportunities for girls and boys in education (85/C 166/01).

Providing equal opportunities for girls and boys in education, elimination of stereotypes in education through awareness campaigns, trainings, meetings, debates, etc., actions and programs undertaken in education, are part of the National Strategy for Gender Equality, Reduction of Gender-based Violence and Domestic Violence, 2011-2015

32000 Y0718(01) $)^{8}$ Communication from the Commission of 7 July 2000 addressed to Member States on the Commission Decision relating to a gender balance within the committees and expert groups established by it (2000/C 203/03).

This communication is partly aligned to the Law no. 9970, dated 24.07.2008 "On gender equality in society" article 15 which requires balanced participation in the executive, judicial, and public structures. Also in line with the National Strategic Goal no. 2 "Strategy for Gender Equality, Reduction of Gender-Based Violence and Domestic Violence", 2011-

\footnotetext{
${ }^{4} \mathrm{http}: / /$ mobile.ikub.al/Article.aspx?ArticleNo=1103110122

5 http://www.mpcs.gov.al/dpshb/en/monitoring/monitoring-reports-

${ }^{6} \mathrm{http}: / /$ eur-lex.europa.eu/LexUriServ/LexUriServ.do?uri=CELEX:41985X0507:EN:NOT

$7 \mathrm{http}: / /$ eur-lex.europa.eu/LexUriServ/LexUriServ.do?uri=CELEX:32000Y0718\%2801\%29:EN:NOT

${ }^{8} \mathrm{http}: / /$ eur-lex.europa.eu/LexUriServ/LexUriServ.do?uri=CELEX:31992H0241:EN:NOT
} 
2015.

In relation to what this document seeks to balance participation and nomination of men and women in the expert groups part of various committees in EU, EC and beyond it is requested to the Ministry of Foreign Affairs to apply this communication in this cases the nomination of experts in different groups or commissions abroad is requested.

31992 $0241^{9}$ Council Recommendation of 31 March 1992 on child care (92/241/EEC) the Council of the European Communities, Having regard to the Treaty establishing the European Economic Community, and in particular Article 235 thereof,

This Council Recommendation deals with providing child care measures and programs to support employees with family responsibilities.

Taking special measures for workers with family responsibilities and awareness activities provided by Law on Gender Equality are provided in the National Strategy for Gender Equality, Reduction of Gender-Based Violence and Domestic Violence, 2011-2015. Also the most recent changes to the Labor Code provide for measures associated with combining work and family responsibilities.

Concrete measures should be envisaged in the Gender Equality Strategy for the years 2015-2020. Specific studies and work with the social partners are provided too.

52008PC0426 ${ }^{10}$ Council Directive on implementing the principle of equal treatment between persons irrespective of religion or belief, disability, age or sexual orientation (presented by the Commission) \{SEC(2008) 2180\}\{SEC(2008) 2181\}

Regarding this Directive the Ministry of Labor, Social Affairs and Equal Opportunities has begun its work on sexual orientation through an action plan, review of legislation and a survey supported by the European Council.

32006D0771 ${ }^{11}$ Decision No 771/2006/EC of the European Parliament and of the Council of 17 May 2006 establishing the European Year of Equal Opportunities for All (2007) — towards a just society

European Parliament's decision to declare 2007 as the European year of equal opportunities for all.

This decision has completed its power to act. Albania has also been part of this campaign.

32004L011312 Council Directive 2004/113/EC of 13 December 2004 implementing the principle of equal treatment between men and women in the access to and supply of goods and services.

This directive is partially aligned with Law. 9970 dated 24.07.2008 "On gender equality in society" regarding definitions and Law no. 10221 dated 4.2.2010 "On protection from discrimination".

31995Y0704(02) ${ }^{13}$ Council Resolution of 27 March 1995 on the balanced participation of men and women in decision-making.

Increase of women's participation in decision-making processes has a number of legal documents and strategic goals in the National Strategy for Gender Equality, Reduction of Gender-Based Violence and Domestic Violence, 20112015, and other programs and projects. However, it should be evaluated in more detail, because it requires the commitment of political parties.

32000 Y $0731(02)^{14}$ Resolution of the Council and of the Ministers for Employment and Social Policy, meeting within the Council of 29 June 2000 "On the balanced participation of women and men in family and working life (2000/C 218/02)

There are several legal provisions in the Law on Gender Equality and Labor Code. The implementation of this resolution requires drafting of new legislation, especially programs and budget, increasing of the supportive services for women and men who work and have children or other dependent persons. In this process should be included social services structures, local government, private sector, etc. Especially, it is required the dialogue with the social partners. 41995X1110(01) ${ }^{15}$ Resolution of the Cuncil and of the representatives of the Governments of the member states, meeting within the Council of 5 October 1995 on the image of women and men portrayed in advertising and the media.

Regarding this resolution Ministry of Labor, Social Affairs and Equal Opportunities, Parliament, the Media Institute and National Council of Radio and Television have their obligations. However the National Strategy for Gender Equality, Reduction of Gender-Based Violence and Domestic Violence, 2011-2015 obligates the media to promote the image of women, to combat gender stereotypes, increase the representation and training of journalists, as cross cutting measures.

\footnotetext{
9 http://eur-lex.europa.eu/LexUriServ/LexUriServ.do?uri=CELEX:52008PC0426:en:NOT

$10 \mathrm{https}: / /$ www.google.al/search?q=32006D0771\&ie=utf-8\&oe=utf-8\&aq=t\&rls=org.mozilla:en-US:official\&client=firefox-a\&channel=fflb

${ }^{11}$ http://eur-lex.europa.eu/LexUriServ/LexUriServ.do?uri=CELEX:32004L0113:en:NOT

${ }^{12} \mathrm{http}: / /$ eur-lex.europa.eu/Result.do?RechType=RECH_celex\&lang=en\&ihmlang=en\&code=31995Y0704\%2802\%29

13 http://eur-lex.europa.eu/LexUriServ/LexUriServ.do?uri=CELEX:32000Y0731\%2802\%29:EN:NOT

${ }^{14} \mathrm{http}: / /$ eur-lex.europa.eu/LexUriServ/LexUriServ.do?uri=CELEX:41995X1110\%2801\%29:EN:HTML

${ }^{15}$ http://eur-lex.europa.eu/LexUriServ/LexUriServ.do?uri=CELEX:31984H0635:EN:NOT
} 
31984H063516 Council Recommendation of 13 December 1984 on the promotion of positive action for women

The Council recommendation has to do with positive measures to promote dignity in employment, encouraging women to participate in the branches of private sector industry dominated by men, to promote equal employment opportunities through awareness; performing surveys on women in the labor market; positive measures to increase the representation and so forth.

Positive measures are foreseen in the Law on Gender Equality in Society, the Labor Code, Law on Protection from Discrimination and the National Strategy for Gender Equality, Reduction of Gender-Based Violence and Domestic Violence, 2011-2015. But the process should continue through undertaking other measures.

$31996 \mathrm{H} 0694^{17}$ Council Recommendation of 2 December 1996 on the balanced participation of women and men in the decision-making process (96/694/EC).

Balanced participation of women and men in decision-making processes is a strategic priority of the National Strategy for Gender Equality, Reduction of Gender-Based Violence and Domestic Violence, 2011-2015, Law on Gender Equality in the Society, and one of the priorities of the government and a request for the EU integration.

Ministry of Labor, Social Affairs and Equal Opportunities, as the responsible authority for gender equality issues can meet the recommendations in collaboration with other stakeholders, institutions at central and local government, social partners, parliament, media, civil society, academic fields, etc.

32003G0724(02) ${ }^{18}$ Council Resolution of 15 July 2003 on Social and Human Capital Building social and human capital in the knowledge society: learning, work, social cohesion and gender.

This resolution has some recommendations on gender mainstreaming in employment, social cohesion and long life learning, including categories such as women with disabilities.

Meeting the recommendation requires to undertake policies and programs, funds and commitment of many stakeholders besides the Ministry of Labor, Social Affairs and Equal Opportunities. Gender Equality Strategy envisages several measures related to achievement of equal opportunities in the labor market between women and men and measures to support the economic empowerment of women.

It is important to understand that Directives, in support and in accordance with the Treaties, are continuously amended and enriched in order to make way for democracy and development.

Albanian Parliament ratified the Council of Europe Convention, "For preventing and combating violence against women and domestic violence" with the Law ${ }^{19}$ no.104/2012 dated 11.08.2012. With the ratification of this Convention, once Albania expresses its commitment to cooperate in regional and international level against gender-based violence and domestic violence, as well as undertaking of legislative, policy and executive measures to fight against this phenomenon.

EU structures on promoting gender equality 20

- Directorate-General for Justice

- European Institute for Gender Equality

- European Parliament Committee on Women's Rights and Gender Equality (FEMM)

- Advisory Committee on Equal Opportunities for Women and Men

- High-Level Group on Gender Mainstreaming

- Group of Commissioners on Fundamental Rights, Non-Discrimination and Equal

Opportunities

- Interservice Group on Gender Equality

- Network of Experts on Gender Equality

- European Network of Legal Experts in the Field of Gender Equality

- European Network of Women in Decision-Making in Politics and the Economy

- Governmental Expert Group in the Field of Non-Discrimination and the

Promotion of Equality

- Network of Socio-economic Experts

${ }^{16}$ http://eur-lex.europa.eu/LexUriServ/LexUriServ.do?uri=CELEX:31996H0694:EN:HTML

${ }^{17} \mathrm{http}: / /$ eur-lex.europa.eu/LexUriServ/LexUriServ.do?uri=CELEX:32003G0724\%2802\%29:EN:NOT

${ }^{18} \mathrm{http}: / /$ mobile.ikub.al/Article.aspx?ArticleNo=1212070213

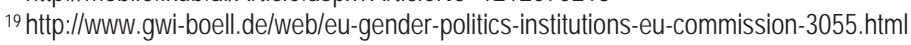

20 http://www.km.gov.al/skedaret/1231927768-Constitution\%20of\%20the\%20Republic\%20of\%20Albania.pdf 
- Network of Legal Experts in the Field of Non-Discrimination

- Expert Group to Promote Inclusion of Ethnic Minorities in the European Union

- European Network of Equality Bodies (EQUINET)

- Council of Europe Steering Committee for Equality between Women and Men

- European Union Agency for Fundamental Rights

\section{Albanian Legal Framework, Policy and Institutions on Gender Equality Issues and Women's Rights}

The main focus of the government in the field of gender equality, in the long term, is the progressive harmonization of Albanian legislation with the Communitys' in the field of working conditions, notably on health and safety at work, and equal opportunities and the cooperation to facilitate the reform of Albanian employment policy, in the context of strengthening economic and integration reforms aiming at the adaptation of the Albanian social security system to the new economic and social requirements, and the adaptation of the Albanian legislation regarding work conditions and equal opportunities for women. (Article 77 and 99 of the SAA).

\subsection{Albanian legal framework on gender equality}

Article 18 of the Constitution of the Republic of Albania ${ }^{21}$ (1998), provides that "all citizens are equal before the law and that no one may be discriminated against on grounds such as gender, race, religion, ethnicity, language, political opinions, religious or philosophical beliefs, economic, educational and social ones. "

The Criminal Code 22 of the Republic of Albania provides for equality between men and women in all areas of life, health, property and dignity. Under this Code, for the same crimes, women receive the same punishment as men. This code addresses a set of offenses and punishment measures for on crimes that are based violence against women. The legislation provides that the commission of criminal offenses on gender motives, constitutes an aggravating factor and increases the penalty for sanction of the author / authors of accomplishment. This provision also provides the aggravating circumstance of committing criminal offenses based on weak motives. The concept of weak motivation is elaborated by jurisprudence by including the killing of women committed in the name of honour (honour crimes). In these circumstances, can decide the appointment of a security period, during which no bail is allowed to the offender (Article 64 of the Criminal Code).

One of the most important legal ammendments is the sanctioning of domestic violence as a criminal offense in the Criminal Code. Domestic violence is a crime provided in Article 130 / a of the revised Criminal Code ${ }^{23}$, which foresees the forms of violence, as well as measures and the subjects protected by this article. Ammendments included systematic psychological and economic abuse, as well as measures to liberate the victims of domestic violence from the obligation to launch prosecution in the case of "minor physical injuries." Article 121 / a "persecution" provides protection of persons in the family, gender or intermarry or cohabiting relationship by threats or harassment and penalties against persons who have caused this to four years.

Civil Code approved by Law no. 8781, dated 03.05.2001, recognizes to women equal rights in all legal processes, such as the right to press lawsuit against someone or to be judged.

The Labor Code $^{24}$ (2003) recognizes the right of equal employment for men and women. Equal rights as well as the protection in the workplace, equal pay for work of equal value and paid vacations. This Code stimulates materially the employer/s for hiring women and girls jobseekers. Formulations of articles of the Labour Code are based on international labor standards.

However during the last two years the Ministry of Labor, Social Affairs and Equal Opportunities has worked to revise the Labour Code of Albania, in order to resolve some problems arising during its implementation in practice. The draft law prepared remarks and reflects the recommendations of the Committee of Experts of the International Labor Organization ILO and the European Committee of Social Rights, and its provisions are harmonized with the acquis communautaire and are taken into consideration the recommendations of the Committee on the Elimination of Discrimination against Women in July 2010.

${ }^{21} \mathrm{http}: / / \mathrm{www}$. lexadin.n//wlg/legis/nofr/eur/arch/alb/PenalCode.pdf

${ }^{22}$ Ammended by the law nr.23, dated 01.03.2012 "On some amendments in the law no.7895, dated 27.01.1995 "Criminal Code of the Republic of Albania" as amended

${ }^{23} \mathrm{http}: / / \mathrm{ww}$.mpcs.gov.al/dpshb/images/stories/files/kodet/3.3.1._Labour_Code_of_Albania.pdf

24http://www.ilo.org/dyn/natlex/docs/ELECTRONIC/65148/89474/F1958881334/ALB65148\%20\%28English\%29.pdf 
Some ammendments that are specifically related to issues and recommendations presented by the CEDAW Committee are as follows:

In the draft revision of the Labour Code, it is provided:

The term "sex", to be replaced with the term "gender" and a more detailed definition is given to the terms "employment and profession"

Prohibition of overtime for pregnant women and women after childbirth, until the child is 1 year old.

Permit required for the postpartum for woman is 63 days.

When a pregnant woman decides to return to work after 63 days and the previous place of work deemed unsuitable for the health and safety of women and children at breastfeeding, the employer's obligation is to adopt the workplace - transfer the woman in a similar and appropriate work. When the transfer is objectively impossible, to the woman is guaranteed benefit under the legislation in force.

- To the women breastfeeding is guaranteed paid leave for child's feeding 2 hours during the working day, or reduction of working time to 2 hours, according to the employer.

- Amendments to Article 115 that guarantees equal remuneration for work of equal value for men and women.

- The definition of sexual harassment is approximated with the EU directive on equal treatment.

- $\quad$ Regarding the burden of proof: "When the issue presented for review to the court and the prosecutor presents evidence of which can pretend discrimination, the defendant must prove that it has been no violation of the principle of equal treatment, or that there was a violation of the principle of equal treatment.

Labor Code provides for some specific rules for the protection of women workers on heavy works. The legislation does not prohibit the legal provisions of night work for women, but under Article 108 of the Labor Code, night work for pregnant women is prohibited. Amendments to the code shall be in acordance to the Article 6 of the Convention no. 171 for night work, 1990, for a more comprehensive approach to the protection of women during and after pregnancy.

Family Code ${ }^{25}$ adopted in 2003, by Law no. 9062/2003, recognizes the equal right of men and women to freely choose marriage and divorce commitments, and mutual rights and obligations to family and children's education. The age of marriage is unified for both men and women (18 years old).

Law ${ }^{26}$ no. 8876, dated 04.04.2002, "On Reproductive Health" supports and guarantees women's reproductive rights. This law highlights that "Every woman free and exempt from any form of discrimination, coercion and violence, has the right to control and to decide freely on all matters relating to her sexuality and sexual and reproductive health . ".

Amendments to Law $9355^{27}$ dated 10.03.2005, "On social assistance and services" (as amended) in 2011, sanctioned the right of economic aid not only to the household, but also to the violated women when they are provided with protective orders from the court. Women have access to benefits and economicaid in cases where spouses are in the process of divorce and no final court decision is given yet.

Law no. $9232^{28}$ dated 13.05.2004 "On Social programes aimed at housing the inhabitants of the urban areas" as amended by Law no. 54/2012, dated 10.05.2012, in Article 5, paragraph 1/c/v has provided social benefit programs to accommodate the "victims of domestic violence" including violated women.

Law no. 9970 dated 24.07.2008 "On Gender Equality in Society"29 supplemented the legal framework on gender equality in education, employment and decision-making. The purpose of this law is: a) to provide effective protection against discrimination on grounds of gender and any form of behavior that incites discrimination because of sex, b) determine the necessary measures to guarantee equal opportunities between women and men, to eliminate genderbased discrimination, in whatever form it appears c) to define the responsibilities of state authorities, central and local, to design and implement normative acts and policies that support the development and promotion of gender equality in society. Innovation that brings the law relating to the introduction of new definitions such as the prohibition of discrimination on grounds of gender, which is consistent with the definition of discrimination provided under CEDAW, gender mainstreaming, definition and prohibition of harassment because of gender, definition of gender equality, the definition of equal gender representation and prediction of temporary special measures in political and public decision provided in the form of quota neutral to the extent of not less than $30 \%$ for the underrepresented sex; definition and allowing as discriminatory of temporary special measures, the creation of new policy structures, executive and protective, the introduction of special measures in the field of education and employment, unpaid work, as well as the obligation to

\footnotetext{
$25 \mathrm{http} / / /$ www.legislationline.org/documents/id/16421

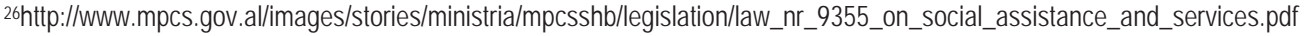

$27 \mathrm{http}: / /$ www.minfin.gov.al/minfin/pub/17_ligj_9232_date_13_may_2004_1319_1.pdf

${ }^{28} \mathrm{http}: / / w w w . m p c s . g o v . a l / d p s h b / i m a g e s /$ stories/files/ligjet/3.4.1.1._Law_on_gender_equality_in_society.pdf

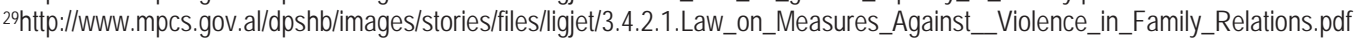


collect gender statistics.

The legal basis for addressing violence is the Law no. 9669, dated 18.12.2006 "On Measures against Domestic Violence" 30 . The adoption and entry into force of this law in 2006 and its amendments in 2007 and 2010 is a further important step towards completing the legal framework in the field of domestic violence. This law has two important directions: First, it stipulates that the state authorities have duties and powers to respond to domestic violence. Second, the law allows courts to issue protection orders against perpetrators, an additional remedy to protect victims of domestic violence. In October 2010 the Albanian Parliament approved several amendments to the law "On measures against domestic violence" supported by the Network of Associations against Gender Violence and Trafficking, UNDP and UNIFEM (now UN Women). These amendments relate to, among other things, the establishment of a national shelter for victims of domestic violence and the legal regulation of coordinated response system and referral to domestic violence cases.

\section{National Policy and Mechanisms on Gender Equality in Albania}

For the first time Albania adopted a National Strategy for Gender Equality, Reduction of Gender-Based Violence and Domestic Violence, 2011-2015, as well as the Action Plan for its implementation, approved by the Council of Ministers no. 573 , dated 16.6.2011.

This strategy is designed on the analysis and treatment of two key issues: Gender Equality and Reduction of Gender Based Violence.

The vision of this strategy is: "A society in which gender equality is respected and valued, taught, supported and encouraged, where gender-based violence of any kind is not tolerated, but punished, while those affected by it are supported and and where equality of opportunity is protected and equal treatment is a reality for all, regardless of gender".

Four priorities are defined: 1) Strengthening Institutional and Legal Mechanism 2) Increasing Women's Participation in Decision-making; 3) Economic Empowerment of Girls and Women; 4) Reducing Gender-Based Violence. The Strategy is also accompanied by a clearly defined action plan associated with measurable and monitorable objectives.

The Action Plan has 14 specific objectives and 113 activities towards achieving Strategic Priority Goals during its implementation by 2011-2015.

The strategy adopted is sensitive to the needs and rights of both genders and attempts to address the needs and rights of comprehensive interventions, especially taking into account the needs of specific groups of women who experience significant disadvantage associated with disabilities, ethnic or social origin and their sexual orientation.

National Strategy for Development and Integration (2007-2013)31, was approved by the Council of Ministers in March 2008.

The aim of this strategy in the field of gender equality is "the achievement of gender equality through the integration of a gender perspective in all aspects of policy formulation and implementation. This means equal participation of women/girls and men/boys in the social, economic and political life of the country, as well as equal opportunities for public services, ensuring equal results for both genders, in order to enjoy all their rights and to put at the service of society, individual potential. "

A special place is given to the importance of treating victims affected by domestic violence, providing information for their protection through civil and criminal legislation, health counseling and social support, prevention and treatment of early signs of violence, and putting the abusers to justice. Actually the National Strategy for Development and Integration 2014-2020 is in the drefting process.

\subsection{National mechanisms on gender equality}

To give a definition on national mechanisms for gender equality, is used the manual on institutional mechanisms for promoting gender equality, prepared by Giorgia Testolin ${ }^{32}$, the Council of Europe in 2001. According to this document, "a gender equality is a government institution and, in some cases, parliamentary structure created to promote the

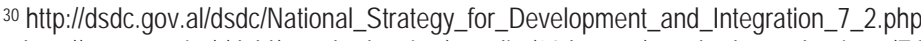

$31 \mathrm{http} / / / \mathrm{www}$. coe.int/t/dghl/standardsetting/equality/03themes/standards-mechanisms/EG\%282001\%297_en.pdf

32 http://www.ilo.org/wcmsp5/groups/public/---ed_protect/---protrav/---ilo_aids/documents/legaldocument/wcms_178702.pdf 
advancement of women and to ensure ownership by women of all their rights. Its main function is to monitor and ensure the implementation of the law, the principle of non-discrimination and equality between men and women "(Testolin, 2001).

According to Law no. 9970 dated 24.07.2008 "On gender equality in society" and Law no. 9669 dated 18.12.2006 "On measures against domestic violence" as amended, the Minister performs the above function through the responsible structure, the Department of Equal Opportunities Policy and the Family which operates since 2006. Its mission is "the formulation and development of policies to promote equality in areas such as gender equality, equality/inequality in skills, problems of ethnic minorities, linguistic and ethno-cultural, age inequalities, generational and racial." After the aproval of the Law No. 10 221, dated 04.02.2010 "On Protection from Discrimination"33, the Directorate was also tasked to work for implementation of this law. This Department consists of two sectors: Gender Equality and On Measures Against Domestic Violence sector and the sector for Child Rights and Protection.

National Council on Gender Equality is established by the Order No. 3 dated 8.1.2009 of the Prime Minister. This is an advisory body for gender policies. In four years, the Council is directed by the Minister responsible for gender equality issues and is composed of nine deputy ministers and three members representing civil society organizations selected through open competition process based on criteria that assess the commitment of these organizations in gender equality.

Gender Focal Point at the Local Level facilitates the collaboration between local government and central government bodies for the implementation and monitoring of legislation and policies on gender equality and domestic violence.

On the steps taken by policy and executive structures of the Albanian state it is visible the continuous development of gender policies, focusing on strengthening the role of women and girls on the social and political development.

Our society still does not accept that the physical, psychological, sexual violence, has irreversible consequences in the development of human personality, there are cases where violence is considered as "necessary" and "useful" or light acts of violence.

Albania is still working and there is too much work to be done in the area of gender equality in the society, to not tolerate gender-based violence of any form, where its victims are protected, integrated as equals in society.

In conclusion of this research, we conclude that concrete measures has to be taken in short term and long term to improve the legal framework on equal opportunities and prevention of domestic violence. Development of measuring criteria and indicators to measure any form of domestic violence. Greater support is needed from central and local government to empower local level mechanisms. The professional development of staffs working directly on this phenomenon as a social, health care, policy and justice system one.

\section{References}

European Partnership with Albania http://europa.eu/legislation_summaries/enlargement/western_balkans/r18011_en.htm Progress Report 2012 on Albania http://www.mie.gov.al/?fq=brenda\&d=6\&gj=gj2\&kid=111

Universal Declaration of Human Rights http://www.ohchr.org/EN/UDHR/Pages/Introduction.aspx

Convention on the Elimination of All Forms of Discrimination against Women (CEDAW) http://www.un.org/womenwatch/daw/ cedaw/cedaw.htm

Law no. 7767 http://mobile.ikub.al/Article.aspx?ArticleNo=1103110122

Monitoring Report of the RA on CEDAW http://www.mpcs.gov.al/dpshb/en/monitoring/monitoring-reports-

CELEX 41985X0507 http://eur-lex.europa.eu/LexUriServ/LexUriServ.do?uri=CELEX:41985X0507:EN:NOT

CELEX 32000Y0718(01) http://eur-lex.europa.eu/LexUriServ/LexUriServ.do?uri=CELEX:32000Y0718\%2801\%29:EN:NOT

CELEX 31992H0241 http://eur-lex.europa.eu/LexUriServ/LexUriServ.do?uri=CELEX:31992H0241:EN:NOT

CELEX 52008PC0426 http://eur-lex.europa.eu/LexUriServ/LexUriServ.do?uri=CELEX:52008PC0426:en:NOT

CELEX 32006D0771 https://www.google.al/search?q=32006D0771\&le=utf-8\&oe=utf-8\&aq=t\&rls=org.mozilla:en-US:official\&client= firefox-a\&channel=fflb

CELEX 32004L0113 http://eur-lex.europa.eu/LexUriServ/LexUriServ.do?uri=CELEX:32004L0113:en:NOT

CELEX 31995Y0704(02) http://eur-lex.europa.eu/Result.do?RechType=RECH_celex\&lang=en\&ihmlang=en\&code=31995Y0704\%2802 $\% 29$

CELEX 32000Y0731(02) http://eur-lex.europa.eu/LexUriServ/LexUriServ.do?uri=CELEX:32000Y0731\%2802\%29:EN:NOT

CELEX 41995X1110(01) http://eur-lex.europa.eu/LexUriServ/LexUriServ.do?uri=CELEX:41995X1110\%2801\%29:EN:HTML

CELEX 31984H0635 http://eur-lex.europa.eu/LexUriServ/LexUriServ.do?uri=CELEX:31984H0635:EN:NOT

${ }^{33}$ L'auteur ajoute qu'afin de le distinguer des préjudices écologiques lésant les intérêts humains, on le désigne souvent par l'expression de préjudice écologique pur. 
CELEX 31996H0694 http://eur-lex.europa.eu/LexUriServ/LexUriServ.do?uri=CELEX:31996H0694:EN:HTML

CELEX 32003G0724(02) http://eur-lex.europa.eu/LeXUriServ/LexUriServ.do?uri=CELEX:32003G0724\%2802\%29:EN:NOT

Law no.104/2012 dated 11.08.2012 On the ratification of the Council of Europe Convention, "For preventing and combating violence against women and domestic violence" http://mobile.ikub.al/Article.aspx?ArticleNo=1212070213

http://www.gwi-boell.de/web/eu-gender-politics-institutions-eu-commission-3055.html

Constitution of the Republic of Albania http://www.km.gov.al/skedaret/1231927768-Constitution\%20of\%20the\%20Republic\%20of \%20Albania.pdf

The Criminal Code of the Republic of Albania http://www.lexadin.nl/wlg/legis/nofr/eur/arch/alb/PenalCode.pdf

The Labor Code http://www.mpcs.gov.al/dpshb/images/stories/files/kodet/3.3.1._Labour_Code_of_Albania.pdf

The Family Code http://www.ilo.org/dyn/natlex/docs/ELECTRONIC/65148/89474/F1958881334/ALB65148\%20\%28English\%29.pdf

Law no. 8876, dated 04.04.2002, "On Reproductive Health" http://www.legislationline.org/documents/id/16421

Law 9355 dated 10.03.2005, "On social assistance and services" (as amended) http://www.mpcs.gov.al/images /stories/ministria/mpcsshb/legislation/law_nr_9355_on_social_assistance_and_services.pdf

Law no. 9232 dated 13.05.2004 "On Social programs aimed at housing the inhabitants of the urban areas" as amended http://www.minfin.gov.al/minfin/pub/17_ligj_9232_date_13_may_2004_1319_1.pdf

Law no. 9970 dated 24.07.2008 "On Gender Equality in Society" http://www.mpcs.gov.al/dpshb/images/stories/ files/ligjet/3.4.1.1._Law_on_gender_equality_in_society.pdf

Law no. 9669, dated 18.12.2006 "On Measures against Domestic Violence" http://www.mpcs.gov.al Idpshb/images/stories/files/ligjet/3.4.2.1.Law_on_Measures_Against_Violence_in_Family_Relations.pdf

National Strategy for Development and Integration (2007-2013) http://dsdc.gov.al/dsdc/National_Strategy_for_ Development_and_Integration_7_2.php

Manual on institutional mechanisms for promoting gender equality, Giorgia Testolin, the Council of Europe in 2001 http://www.coe.int//dghl/standardsetting/equality/03themes/standards-mechanisms/EG\%282001\%297_en.pdf

Law No. 10 221, dated 04.02.2010 "On Protection from Discrimination" http://www.ilo.org/wcmsp5/groups/public/---ed_protect/--protrav/---ilo_aids/documents/legaldocument/wcms_178702.pdf 